\title{
Does the Use of Metacognitive Strategies Influence Students' Problem Solving Skills in Physics?
}

\author{
Shareeja, Ali. M. C., \& Gafoor, Abdul. K.
}

\section{Problem solving in Education}

Problem solving is the most important learning outcome of educational endeavors (Gagne, 1980). All the sciences, both pure and applied, are centrally concerned with developing and systematizing knowledge that is useful for solving various kinds of problems. Problem solving as a goal-directed behavior requires an appropriate mental representation of the problem and the subsequent application of certain methods or strategies in order to move from an initial state to a desired goal state (Metallidou, 2009).

Problem solving is viewed as a fundamental part of science education in regular schools (Reif, Larkin \& Brackett, 1976; Larkin \& Reif, 1979; Chi, Feltovich \& Glaser, 1981; Reif, 1981; Bascones, Novak \& Novak, 1985; Amigues, 1988; Robertson, 1990; Savage \& Williams, 1990; McDermott, 1991; Heller, Keith \& Anderson, 1992; Henderson, Heller, Heller, Kuo \& Yerushalmi, 2001; Kuo, 2004; Pol, 2005; Yerushalmi \& Magen, 2006; Loucks, 2007). Academic problems in this context follow some well-defined criteria: all information needed to solve the problem is given; a limited set of rules are needed to solve the problem; in many cases, only one procedure leads to the right answer; and there is only one correct answer.

Many of the researchers examined general (Polya, 1945; Dewey, 1910; Kneeland, 1999) and specific problem solving strategies. In addition to these strategies, numerous problem-solving methods were developed to help students improve their understanding and problem solving skills in physics in particular. Some such strategies involve the didactic approach (Bagno \& Eylon's , 1997); the collaboration method (Harskamp \& Ding, 2006); the computer-assisted instruction model (Bolton \& Ross, 1997; Pol, 2005); the translating context-rich problem approach (Heller, Keith \& Anderson, 1992; Heller \& Hollabaugh, 1992; Yerushalmi \& Magen, 2006); the creativeness approach in problem solving (Johnstone \& Otis, 2006; Walsh, Robert \& Bowe, 2007; Cooper, Cox, Nammouz \& Case, 2008; Bennett, 2008) and the epistemic games (Tuminaro \& Redish, 2007). Recent studies examine how metacognition helps problem-solving (Anderson \& Nashon, 2005).

\section{Metacognitive Strategies in Problem solving}

The term metacognition refers to a students' knowledge about his/her processes of cognition and the ability to control and monitor those processes as a function of the feedback received via outcomes of learning. Metacognitive activity can be specified in terms of its components namely planning, monitoring and evaluation (Van Hout- Wolters, Simons, \& Volet, 2000). According to Flavell (1979) they are the main components at the highest hierarchical level of metacognitive activities before commencing a task, during execution of the task, and upon completion of the task, respectively.

Recent studies on enhancing domain specific problem-solving strongly recommend the use of metacognitive strategies. They argue that students may not know how to use the instruction effectively, thus they might benefit from metacognitive instruction on how to learn (Roll, Aleven, McLaren, Ryu, Baker \& Koedinger, 2006). When new information and domain specific knowledge are held constant, reflective thinking processes that encourage elaboration on a problem are instrumental in providing the most efficient problemsolving. This is because high metacognitive skills can compensate for deficit in overall ability by providing knowledge about their own cognition.

\section{Influence of Metacognitive Strategies on Problem Solving}

Although the relation of metacognition with learning results is the subject of many educational studies (Sperling, Howard,Miller, \&Murphy, 2002; Veenman, Elshout, \& Meijer, 1997; Wang, Haertel, \& Walberg, 1990), it is by no means clear which particular metacognitive activities are related to problem solving skills particularly to physics. Identifying these activities may render suggestions for metacognitive training. Present study explores the metacognitive strategies adopted by higher secondary school students and investigates how the strategy is related to their problem solving skills in physics, especially mechanics. 


\section{Methodology}

The study employs a survey to assess the extent of use of metacognitive strategies by higher secondary school students. It also examines how far the use of such strategies influences the problem solving skills of students.

\section{Objectives of the Study}

1. To find out the extent of specific metacognitive activities adopted by higher secondary school students

2. To find the relationship between metacognitive learning strategies and problem solving skills in physics among higher secondary school students

\section{Sample}

The sample consists of 104 higher secondary school students. There were 64 boys and 40 girls. Three schools were selected from Kozhikode district in Kerala state in India. All the three schools were government managed and were from urban area.

Tools

The study employs the following tools developed by the researchers.

1. Scale of Metacognitive Strategies

This tool consists of 20 items to assess the various metacognitive practices related to planning (6 statements), monitoring (7 statements), and evaluation (7 statements). The statements were rated on a five point Likert- type scale.

2. Test on Problem solving In Mechanics

This tool consists of 36 problems from mechanics taught at higher secondary level. The students have to choose the solution from four alternatives. This particular domain was selected because though related to everyday life enabling concrete thinking, mechanics is often perceived difficult and students seems reluctant to attempt to solve problems from mechanics.

\section{Analysis of metacognitive learning strategies}

\section{Results}

Analysis of responses on Scale of Metacognitive Strategies reveals that there is a fair practice of metacognitive strategies by the students. Most of the students (about 75\%) have set an academic goal. Only half of them (about 50\%) have planned a route to attain the goal.

About $50 \%$ of the students prepares a timetable for study purpose, identifies their strength and weaknesses, give more concentration towards important concepts while learning, adopt varying and appropriate methods for learning different subjects, voluntarily seeks the help of teachers and other friends. As far as the use of metacognitive strategies in problem solving is concerned, about $50 \%$ of the student's attempts to solve problems themselves, look for analogical strategies previously used to solve a new problem, check the feasibility of the attained solution.

Only very few (less than 25\%) students believe that they can attain anything they aspire with hard work. Only very few evaluate whether they have completed the tasks as per the plan. Students rarely make memory tips while learning.

\section{Relationship between metacognitive strategies and problem solving}

There is a positive correlation between metacognitive strategies and problem solving $(\mathrm{r}=0.78)$.

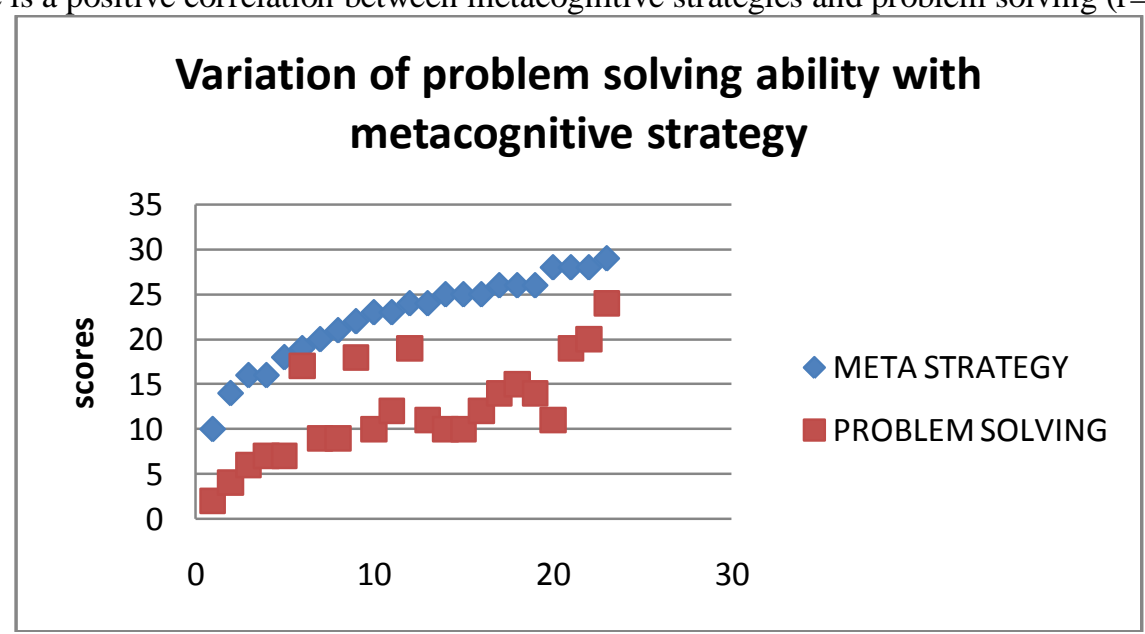

Figure 1: Variation of problem solving skills with metacognitive strategies 
The figure visually represents the variation of problem solving skill with the practice of metacognitive strategies. Though there is no perfect correlation, except for a few there is increase in problem solving skills with the use of metacognitive strategies.

\section{Conclusion}

The study reveals that there is positive influence of the use of metacognitive strategies on problem solving skills. Though students practice regular academic planning, they rarely monitor their learning activities and seldom evaluate learning outcomes. One reason for students to be better in planning than the other components, the investigators assume, is that goal setting, planning, motivating are subject matter of programmes conducted by guidance and counseling cell in every school. There is further need to motivate students more rigorously monitor and continuously self evaluate their learning while solving problems. This will require subject teachers to help in planning, to provide continuous feed back based on the monitoring of problem solving process and to adopt classroom strategies that enhance peer and teacher evaluation of student progress in the initial phase of training for problem solving. Teachers have to take care that they progressively withdraw this facilitation process as students increasingly become fluent on metacognitive strategies.

\section{References}

[1]. Amigues, R. (1988). Peer interaction in solving physics problems: Sociocognitive confrontation and metacognitive aspects. Journal of Experimental Child Psychology, 45, 141-158.

[2]. Anderson, D., \& Nashon, S. (2005). Predictors of knowledge construction: interpreting students' metacognition in an amusement park physics program. In D. D. Lynn \& F. H. John (eds.). Science Learning in Everyday Life. Wiley Periodicals, Inc. 1-23.

[3]. Bagno, E., \& Eylon, Bat-S. (1997). From problem solving to a knowledge structure: An example from the domain of electromagnetism. American Journal of Physics, 65, 726-736.

[4]. Bascones, J., Novak, V., \& Novak, J. D. (1985). Alternative instructional systems and the development of problem-solving skills in physics. European Journal of Science Education, 7(3), 253-261.

[5]. Bennett, W. (2008). Problem solving: can anybody do it? Chemistry Education Research and Practice, 9, 60-64.

[6]. Bolton. J., \& Ross, S. (1997). Developing students' physics problem-solving skills. Physics Education, 32, $176-185$.

[7]. Chi, T., Feltovich, P., Glaser, R. (1981). Categorization and representation of physics problems by experts and novices. Cognitive Science, 5, 121-152.

[8]. Cooper, M., Cox, C., Nammouz, M., Case, E. (2008). An assessment of the effect of collaborative groups on students' problemsolving strategies and abilities. Journal of Chemical Education, 85, 866-872.

[9]. Dewey, J. (1910). How we think. London: D. C. Heath \& Company.

[10]. Flavell, J. H. (1979). Metacognition and cognitive monitoring. A new area of cognitive developmental inquiry. American Psychologist, 34(10), $906-911$.

[11]. Gagne, R.M. (1980). The conditions of learning. New York: Holt, Rinehart, \& Winston.

[12]. Harskamp, E., \& Ding, N. (2006). Structured collaboration versus individual learning in solving physics problems. International Journal of Science Education, 14, 1669-1688.

[13]. Heller, P., \& Hollabaugh, M. (1992). Teaching problem solving through cooperative grouping. Part 2: Designing problems and structuring groups. American Journal of Physics, 60, 637-644.

[14]. Heller, P., Keith, R., \& Anderson, S. (1992). Teaching problem solving through cooperative grouping. Part 1: Group versus individual problem solving. American Journal of Physics, 60, 627-636.

[15]. Henderson, C., Heller, K., Heller, P., Kuo, V. H., \& Yerushalmi, E. (2001). Instructors' ideas about problem solving - Setting goals. Proceedings of Physics Education Research Conference, Rochester, New York, July 2001.

[16]. Johnstone, H., \& Otis, H. (2006). Concept mapping in problem based learning: a cautionary tale. Chemistry Education Research and Practice, 7, 84-95.

[17]. Kneeland, S. (1999). Effective problem solving: How to understand the process and practice it successfully. How to Books.

[18]. Kuo, V. (2004). An explanatory model of physics faculty conceptions about the problem solving process.

[19]. Larkin, H., \& Reif, F. (1979). Understanding and teaching problem-solving in physics. European Journal of Science Education, 1, 191-203.

[20]. Loucks, S. E. (2007). Introductory physics with algebra: Mastering problem-solving. US: John Wiley \& Sons.

[21]. McDermott, C. (1991). Millikan Lecture 1990: What we teach and what is learned-closing the gap. American Journal of Physics, 59, 301-315.

[22]. Metallidou, P. (2009). Pre-service and in-service teachers' metacognitive knowledge about problem-solving strategies. Teaching and Teacher Education, 25, 76-82.

[23]. Pol, H. (2005). Solving physics problems with the help of computer-assisted instruction. International Journal of Science Education, 27, 451-469.

[24]. Polya, G. (1945). How to solve it. New Jersey: Princeton University Press.

[25]. Reif, F. (1981). Teaching problem solving: A scientific approach. The physics Teacher, 19, 310-316.

[26]. Reif, F., Larkin, H., \& Brackett, C. (1976). Teaching general learning and problem-solving skills. American Journal of Physics, 44, 212-217.

[27]. Robertson, W. C (1990). Detection of cognitive structure with protocol data: Redirecting performance on physics transfer problems. Cognitive Science, 14, 253-280.

[28]. Roll, I., Aleven, V., McLaren, B., Ryu, E., Baker, R. S., \& Koedinger, K. R. (2006). Does metacognitive feedback improve student's help seeking actions, skills and learning? In Intelligent Tutoring Systems: 8th International Conference, ITS 2006 (360369). Berlin: Springer.

[29]. Savage, M., \& Williams, J. (1990). Mechanics in action-modelling and practical investigations. Cambridge: Cambridge University Press.

[30]. Sperling, R. A., Howard, B. C., Miller, L. A., \& Murphy, C. (2002). Mea sures of children's knowledge and regulation of cognition. Contemporary Educational Psychology, 27, $51-79$. 
[31]. Tuminaro, J., \& Redish, F. (2007). Elements of a cognitive model of physics problemsolving: Epistemic games. Physical Review Special Topics-Physics Education Research, 3, 1-22.

[32]. Van Hout-Wolters, B. H. A. M., Simons, P. R. J., \& Volet, S. (2000). Active learning: Self-directed learning and independent work. In P. R. J. Simons, J. L. van der Linden, \& T. Duffy (Eds.), New learning (pp. 73 - 89). Dordrecht, The Netherlands: Kluwer.

[33]. Veenman, M. V. J., Elshout, J. J., \& Meijer, J. (1997). The generality vs domain-specificity of metacognitive skills in novice learning across domains. Learning and Instruction, 7(2), $187-209$.

[34]. Walsh, N., Robert, H., \& Bowe, B. (2007). Phenomenographic study of students' problem solving approaches in, physics. Physical Review Special Topics-Physics Education Research, 3, 1-12.

[35]. Wang, M. C., Haertel, G. D., \& Walberg, H. J. (1990). What influences learning? A content analysis of review literature. Journal of Educational Research, 84(1), 30 - 43.

[36]. Yerushalmi, E., \& Magen, E. (2006). Same old problem, new name? Alerting students to the nature of the problem-solving process. Physics Education, 41, 161-167. 